\title{
Verbal Abuse on Children: Does It Amount to Child Abuse under the Malaysian Law?
}

\author{
Che Hasniza Che Noh $^{1} \&$ Wan Izatul Asma Wan Talaat ${ }^{2}$ \\ ${ }^{1}$ Faculty of Social Development, Universiti Malaysia Terengganu, Kuala Terengganu, Malaysia \\ ${ }^{2}$ Faculty of Management \& Economics, Universiti Malaysia Terengganu, Kuala Terengganu, Malaysia \\ Correspondence: Wan Izatul Asma Wan Talaat, Faculty of Management \& Economics, Universiti Malaysia \\ Terengganu, 21030 Kuala Terengganu, Terengganu, Malaysia. Tel: 60-9-668-4273/60-19-936-3808. E-mail: \\ wia@umt.edu.my
}

Received: December 22, $2011 \quad$ Accepted: February 2, $2012 \quad$ Published: May 1, 2012

doi:10.5539/ass.v8n6p224 URL: http://dx.doi.org/10.5539/ass.v8n6p224

\begin{abstract}
Children form an essential component of a society. The role of children has been acknowledged key to the survival, development as well as prosperity of that society. A child's development stage is the most crucial and warrants serious attention from parents and teachers in order to assure their growth into mature adults, who are able to contribute to the society. One of the factors that may hamper their growth is child abuse. There are basically five main forms of child abuse known to take place in Malaysia namely physical abuse, sexual abuse, emotional abuse, neglect as well as abandonment. These forms of abuse have been given legal attention and recognition except emotional or psychological abuse. One common type of emotional abuse is verbal abuse, which is a form of abusive behavior involving the use of language. Alternatively known as reviling, it is a pattern of behavior that can seriously interfere with one's positive emotional development and over time, it can lead to significant detriment to one's self-esteem, emotional well-being and physical state. Although verbal abuse does not leave any outer mark or proof, a verbally abused victim usually suffers by having lower self-worth and low self-esteem. A child, who suffers verbal abuse may grow up to become a low self-esteem adult. Thus, verbal abuse may be considered as grave and must be given serious attention. Laws are the reflection of the attitude of a particular society. Since the function of law is mainly to maintain societal peace and order, it is through law that we can infer how society regards a particular issue, in this regard, verbal abuse on children. This paper aims to highlight firstly, on verbal abuse as another significant form of child abuse needing to be given serious consideration by the society and secondly, on the parameters of child abuse under the Malaysian Child Act 2001; and finally concludes with whether the provisions under the Malaysian Child Act 2001 are sufficient to protect children from verbal abuse.
\end{abstract}

Keywords: verbal abuse, child development, child abuse, Malaysian child law

\section{Introduction}

Every child has the right to health and a life free from violence. Each year, thousands of children in Malaysia are reported as victims of child abuse and neglect. Child abuse is a huge global problem with a serious impact on the child's physical and mental health, well-being and development throughout their live.

As such, it poses problem for the society in general. Child abuse refers to the physical and emotional mistreatment, sexual abuse, neglect and negligent treatment of children, as well as to their commercial or other exploitation. Child abuse is generally divided into four different types of abuse which are: physical abuse, sexual abuse, emotional abuse and neglect. One common type of emotional abuse is verbal abuse.

\section{Verbal Abuse}

Verbal abuse, according to Grady (2003), can be defined as "words that attack or injure an individual, words that cause one to believe an untrue statement, or words that speak falsely of an individual". Verbal abuse is a kind of battering which doesn't leave evidence comparable to the bruises of physical battering. Verbal abuse is often more difficult to see since there are rarely any visible scar unless physical abuse has taken place. Although verbal abuse does not leave any outer mark or proof, a verbally abused victim usually suffers by having lower self-worth and low self esteem. 
According to Grady (2003), verbal abuse is worse than physical abuse as verbal abuse constitutes psychological violence. It is much more insidious as it attacks the emotional as well as the mental. This is supported by Brendgen et al. (2006), whose research reveals that verbal abuse can be considered as a part of the broader concept of psychological abuse or maltreatment against children. Garbarino et al. (1986) describe verbal abuse as emotional abuse, an attack on a child's development of self and social competence, and a pattern of psychically destructive behavior.

There are many types of communication behaviours that may be construed as verbal abuse and there have been numerous interpretations on what constitutes a verbal abuse. Brendgen et al. (2006), for instance, view that behaviours generally subsumed within the context of verbal abuse are ridiculing and teasing, name calling, yelling, verbal putdowns, negative prediction, negative comparison, shaming, cursing and swearing, and threats at the child. Anderson (2002) lists down seven categories of verbal abuse namely withholding, countering, discounting, jokes, blocking and diverting, accusing and blaming, and judging and criticizing.

Another categorisation of verbal abuse is trivializing, undermining, threatening, name-calling, forgetting, ordering and denial. The studies conducted by Cook et al. (2001) and Oweis and Diabat (2005) have clearly divided verbal abuse into eleven categories i.e. judging and criticizing, accusing and blaming, abusive anger, discounting, condescending, ignoring, trivializing, blocking and diverting, threatening, abuse disguised as jokes, and sexual harassment. Another interesting and comprehensive understanding of verbal abuse has been noted by Evans (1993), who lays down 15 types of verbal abuse: withholding, verbal abuse disguised as jokes, trivializing, judging and criticizing, blocking and diverting, name calling, countering, discounting, accusing and blaming, undermining, forgetting, ordering and demanding, denial, abusive anger, and threatening.

In a more streamlined approach, Vardigan (2009) opines that verbal abuse from parents on a child may take place in the following modes:

i) Name calling, belittling, swearing, insulting. ("You are stupid!"; "You're a rotten kid")

ii) Rejecting or threatening with abandonment. ("I wish you'd never been born."; "I should put you up for adoption.") This kind of verbal abuse creates a sense that the child doesn't belong, and isn't wanted in the family.

iii) Threatening bodily harm. Studies have linked verbal aggression and physical aggression: Quoting a Harvard study - "parents who yell frequently are the ones most likely to hit frequently, and vice versa."

iv) Scapegoating or blaming. ("You're the reason this family is such a mess!"; "If I didn't have to take care of you, I could have a better life."; "If you weren't so clumsy, your sister wouldn't have gotten hurt.") The child will think he's a bad person who deserves to be unhappy.

v) Using sarcasm. Making a mocking remark, such as "Now that was smart" when child spills grape juice on the rug, might seem like a way to avoid direct criticism, but the child is perceptive enough to understand that the parents demeaning him.

\subsection{Verbal Abuse and Child Development}

In the midst of its multiple interpretations, the fact remains that verbal abuse may inevitably affect a victim's psychological and mental health. Although the scars may be invisible, its gravity is paramount especially when the victim is a child, who may well have to carry the scars until adulthood. According to Moore et al. (2006), psychological maltreatment, including verbal aggression, has been implicated as an important contributor to children's behavioural problems. Teicher et al. (2006) notes that verbal aggression is associated with moderate to large effects, comparable to those associated with witnessing domestic violence or non-familial sexual abuse and larger than those associated with familial physical abuse.

Exposure to verbal aggression in childhood may lead to the following conditions:

i) A stressor that affects the development of certain vulnerable brain regions in susceptible individuals, resulting in psychiatric sequelae.

ii) The creation of force a powerful negative model for interpersonal communication subsequently incorporated as a behavioural response in future relationships.

Vardigan (2009) further adds that the indication of child is being victimised on verbal abuse is negative self-image (for e.g.:- "nobody likes me", "I'm stupid"), self-destructive acts, antisocial behaviour and delayed development. Verbal abuse or psychological maltreatment can lead to serious negative consequences on child and adolescent development and behaviour. There are numerous evidences pointing towards the effect of child 
abuse on children. Sachs-Ericsson (2006) for instance, suggest that childhood abuse experiences, and in particular verbal abuse, may confer risk for internalizing disorders in part because verbal abuse influences the development of a self-critical style.

Spillane-Grieco (2000) reports that verbally abused teenagers tend to be more physically aggressive, misuse of substance and runaway from home. It has also been revealed that parental verbal abuse saddens, hurts, frightens, frustrates, and undermines self-esteem of its victim (Esteban, 2006). This revelation is supported by Pagani et al. (2009), who view that in terms of parental practices, instead of corporal punishment, verbal punishment in is likely to culminate in aggression toward fathers during adolescence. It was found that harsh verbal punishment by parents builds up the odds of child-directed aggression against fathers.

Standing on the same ground is Keller (2009), who finds that child behaviour problems were related to parental use of verbal and corporal punishment and were detrimental to the quality of the parent-child relationship. According to Spillane-Grieco (2000), criminal offender teenagers, who rated themselves for aggression, both physical and verbal, discloses the use of physical and verbal aggression between their parents and between their parents and themselves as well as extreme use of verbal abuse in their families. These experiences were not found on non-criminal offenders.

In a more appalling finding by Doak (2007), parents who verbally abuse their children are also more likely to physically abuse their children and the 1985 survey finds that verbally abusive mothers physically abuse their children about nine times more than others mothers and similarly, fathers who were verbally aggressive towards their children physically abuse the children more than three times as much as other fathers.

Brendgen et al. (2007), who studied on teacher psychological abuse, finds that verbal abuse by the teacher during childhood was positively related to behaviour problems and for girls, a low probability of having obtained a high school diploma by age 23 years. The teacher psychological abuse took in the forms of teacher's verbal attacks on the student's character or ability (for e.g. name-calling, yelling, or public ridicule) or acts of neglect (for e.g. ignoring). It is further viewed that if a child is repeatedly told that his or her performance on academic tasks is due to his or her stupidity, he or she may eventually come to believe it and over the time, the child may begin making these types of attributions for poor performance on any academic task. In addition to that, an earlier study by Brendgen et al. (2006) divulges that verbal abuse by the teacher is significantly related to subsequent delinquent behaviour and academic difficulties in early adolescence, although this effect depends on child characteristics.

Although the loss or injury suffered by a verbal abuse child victim cannot be precisely quantified, the effects of such abuse are not to be brushed aside. A child victim suffering from verbal abuse may lose his childhood thereby affecting his physical and psychological development as observed by Vachss (1994) that the costs of emotional abuse cannot be measured by visible scars, but each victim loses some percentage of capacity.

\section{Child Abuse under the Malaysian Law}

Malaysia is a State Party to the Convention on the Rights of the Child, which was adopted by the United Nations General Assembly on 20 November 1989. This Convention was ratified by all nations except the United States and Somalia. Malaysia ratified the Convention in February of 1995. This Convention is a compilation and clarification of children's human rights, which sets out the necessary environment and means to enable every human being to develop to their full potential. According to UNICEF, the articles of the Convention work in twofold namely by:

i) Laying down the foundational principles from which all rights must be achieved; and

ii) Calling for the provision of specific resources, skills and contributions necessary to ensure the survival and development of children to their maximum capability.

The Convention places equal emphasis on all of the rights for children. There is no such thing as a "small" right and no hierarchy of human rights. These rights are indivisible and interrelated, with a focus on the child as a whole. Governmental decisions with regard to any one right must be made in the light of all the other rights in the Convention (UNCHR, 2001).

The articles in the Convention also require the creation of means to protect children from neglect, exploitation and abuse by means of legislative, administrative and policy measures. By ratifying the Convention, Malaysia accepts an obligation to respect, protect, promote and fulfil the enumerated rights including by adopting or changing laws and policies that implement the provisions of the Convention. In ratifying the Convention, Malaysia has expressed her reservations as follows, 
"The Government of Malaysia accepts the provisions of the Convention on the Rights of the Child but expresses reservations with respect to articles $1,2,7,13,14,15,[\ldots], 28$, [paragraph 1 (a)] 37, [...] of the Convention and declares that the said provisions shall be applicable only if they are in conformity with the Constitution, national laws and national policies of the Government of Malaysia."

The Malaysian law on children is governed by the Child Act 2001, which was passed as an effort to carry out her obligation under the Convention. This Act consolidates three of its previous laws on child protection and juvenile courts namely the Juvenile Court Act 1947, Women and Girls Protection Act 1973 and Child Protection Act 1991. The Child Act 2001 makes reporting of child abuse mandatory where Chapter 3 is devoted to offences in relation to the health and welfare of children. Child abuse is specifically provided under Section 31(1)(a), which prohibits any person, who has the care of a child from abusing, neglecting, abandoning or exposing the child in a manner likely to "cause him physical or emotional injury". Such person is also prohibited from causing or permitting the child to be so abused, neglected, abandoned or exposed.

The term "abuse" is used generally without referring to the various types of abuse. Other than child sexual abuse, which receives specific mention under Section 3(1)(b), the Act is silent on the other types of abuse but speaks rather broadly by mentioning the impact of the abuse as to "cause him physical or emotional injury". It may be inferred that from the legislators' point of view, since verbal abuse leaves no physical scar, it does not merit special protection under the Child Act. Albeit the broad mentioning of "emotional injury", the Act is silent in further explaining or describing this type of injury.

It must be noted that abuse and injury have two different connotations: the act and the effect of such act. A physically abused person may suffer both physical and emotional injuries although the same cannot be said for emotional abuse, which includes verbal abuse. By omitting to mention and describe the word "emotional abuse", the Child Act may not be sufficient to cover verbal abuse or in a broader sense, emotional abuse.

\section{Conclusion}

From the above discussions, it can be surmised that verbal abuse does influence a child's development in a negative way with some extreme cases leading towards child delinquencies. In less extreme cases, verbally abuse children may also grow into low self-esteemed adults. According to UNICEF, Governments are obliged to recognize the full spectrum of human rights for all children and consider children in legislative and policy decisions. While many States are beginning to listen seriously to children's views on many important issues, the process of change is still in its earliest stages. Verbal abuse may not leave any physical scar on a child's body but the unseen damage could be enormous. Children must also be protected from all kinds of abuse including verbal abuse.

In Malaysia, the legal recognition for verbal abuse and other forms of emotional abuse is still lacking and the future for a comprehensive protection for children is still bleak. Until and unless all kinds of child abuse is given cognizance by the Child Act 2001, there would still be loopholes in this Act, which were meant to provide for the care and protection of children in Malaysia. Despite the reservations made by Malaysia in ratifying the Convention on the Rights of the Child, which are mostly due to religious, customary and constitutional limitations peculiar to multicultural nations like Malaysia, the Child Act 2001 should have provided clearer provisions on emotional abuse.

By merely extending the impact of child abuse to also include "emotional injury", the existing provisions of the Act is still insufficient to cater for other injuries than physical injuries. No religious, customary and constitutional limitations should be taken as an excuse to exclude emotional abuse from the definition of child abuse under the Malaysian law. It is therefore recommended that, in order to guarantee safe and healthy development of children in Malaysia, the existing Child Act should be reviewed and reformed.

\section{References}

Anderson, K. (2002). Verbal abuse. Retrieved 18/02, 2009, from http://.www.leaderu.com/orgs/probe/docs/verbalabuse.html

- (2002). Child abuse. Retrieved 18/02, 2009, from
http://www.myhealth.gov.my/myhealth/eng/kanak_content.jsp?lang=kanak\&storyid=1196299223864\&storymas ter $=1130128997551 \&$ storymaster $2=1196299223864 \#$

Brendgen, M., Bukowski, W. M., Wanner, B., Vitaro,F., \& Tremblay, R.E. (2007). Verbal abuse by the teacher during childhood and academic, behavioral, and emotional adjustment in young adulthood. Journal of educational psychology, 99, 26-38. 
Brendgen, M., Wanner, B., \& Vitaro, F. (2006). Verbal abuse by the teacher and child adjustment from kindergarten through grade 6. Pediatrics, 117, 1585-1598. http://dx.doi.org/10.1542/peds.2005-2050

Cook, K.J., Green, M., \& Topp, R.V. (2001). Exploring the Impact on Physician Verbal Abuse on Nurses. Aorn Journal, 74, 237-241. http://dx.doi.org/10.1016/S0001-2092(06)61787-0

Doak, M. J. (2007). Child abuse and domestic violence. London: Thomson.

Esteban, E. J. (2006). Parental verbal abuse: Culture-spesific coping behavior of college students in the Philipines. Child psychiatry and human development, 36, 243-259. http://dx.doi.org/10.1007/s10578-005-0001-6

Evans, P. (1993). Verbal Abuse Survivors Speak Out: On Relationship and Recovery. Holdbrook, MA: Adams Media Corporation.

Figer, R. C. (2008). Looking through the eyes of the child: The phenomenon of child verbal abuse in the Philippines. Relational Child \& Youth Care Practice, 21, 46-58.

Garbarino, J., Guttman, E., \& Seeley, J.W. (1986). The Psychologically Battered Child: Strategies or Identification, Assessment, and Intervention. In Esteban, E.J. (Ed.), Parental Verbal Abuse:Culture-Specific Coping Behavior of College Students in the Philippines. Child Psychiatry and Human Development, 36, 863-870.

Grady, J. (2003). Stop Verbal Abuse. Houston: Therepia Publishing.

Keller, K., \& Fox, R.A. (2009). Toddlers with developmental delays and challenging behaviors. Early child development \& Care, 179, 87-92. http://dx.doi.org/10.1080/03004430600987126

Moore, T., \& Pepler, D. (2006). Wounding words: Maternal verbal aggression and children's adjustment. Journal of Family Violence, 21, 89-93. http://dx.doi.org/10.1007/s10896-005-9007-x

Oweis, A., \& Diabat, K.M. (2005). Jordanian Nurses Perception of Physicians' Verbal Abuse: Findings from a Questionnaire Survey. International Journal of Nursing Studies, 42, 881-888. http://dx.doi.org/10.1016/j.jinurstu.2004.11.005

Pagani, L., Tremblay, R., Nagin, D., Zoccolillo, M., Vitaro, F., \& McDuff, P. (2009). Risk factors models for adolescent verbal and physical aggression toward fathers. Journal of Family Violence, 24, 173-182. http://dx.doi.org/10.1007/s10896-008-9216-1

Sachs-Ericsson, N., Verona, E., Joiner, T., \& Preacher, K.J. (2006). Parental verbal abuse and the mediating role of self-criticism in adult internalizing disorders. Journal of Affective Disorders, 93, 71-78. http://dx.doi.org/10.1016/j.jad.2006.02.014

Spillane-Grieco, E. (2000). From parent verbal abuse to teenage physical aggression? Child and Adolescent Social Work Journal, 17, 411-430. http://dx.doi.org/10.1023/A:1026427710320

Teicher, M.H., Samson, J.A., Polcari, A., \& Mcgreenery, C.E. (2006). Sticks, stones, and hurtful words: Relative effects of various forms of childhood maltreatment. American Journal of Psychiatry, 163, 993-1000. http://dx.doi.org/10.1176/appi.ajp.163.6.993

Unite for Children. Retrieved 20/3, 2009, from http://www.unicef.org/crc/

United Nations Treaty Collection [As of 9 October 2001] -Declarations and Reservations. Retrieved 20/3, 2009, from http://www.unhchr.ch/html/menu3/b/treaty15_asp.htm

Vachss, A. (1994). You Carry the Cure in Your Own Heart. Parade Magazine, August 28. Retrieved 20/3, 2009, from http://www.vachss.com/av_dispatches/disp_9408_a.html

Vardigan, B. (2009). Verbal abuse of children. Retrieved 20/3, 2009, from http://www.ahealthyme.com/topic/printview 